\title{
Treatment of RO Rejects Wastewater by Integrated Coagulation Cum Adsorption Process
}

\author{
M. Senthil Kumar ${ }^{*}$, G. Kalyani², S. Mahendran ${ }^{3}$, H. Joga Rao \\ R. Gokulan ${ }^{5}$, R. Someswaran ${ }^{6}$, C. Jenifa Latha ${ }^{7}$, M. Palpandian ${ }^{8 *}$ \\ ${ }^{1}$ Department of Civil Engineering, Sethu Institute of Technology, > Kariapatti, Virudhunagar, Tamil Nadu - 626115 \\ ${ }^{2}$ Department of Civil Engineering, Nadimpalli Satyanarayana Raju Institute of Technology, Visakhapatnam, \\ Andhra Pradesh - 531173 \\ ${ }^{3}$ Department of Civil Engineering, PSNA College of Engineering and Technology, Dindigul, Tamil Nadu - 624622 \\ ${ }^{4}$ Department of Chemical Engineering, GMR Institute of Technology, Rajam, Srikakulam, Andhra Pradesh - 532127 \\ ${ }^{5}$ Department of Civil Engineering, GMR Institute of Technology, Rajam, Srikakulam, Andhra Pradesh - 532127 \\ ${ }^{6}$ Department of Civil Engineering, V.S.B Engineering College, Karur, Tamil Nadu, India - 639111 \\ ${ }^{7}$ Department of Civil Engineering, Saveetha Engineering College, Saveetha Nagar, Chennai, Tamil Nadu - 602105 \\ ${ }^{8}$ Department of Electrical and Electronics Engineering, Thamirabharani Engineering College, Tirunelveli -627358
}

Received: 22 July 2020

Accepted: 6 November 2020

\begin{abstract}
This research proposed to treat the RO rejected wastewater in a household plant by the integrated treatment system. The possibility of wellhead water treatment by the combined treatment system of coagulation and adsorption for salinity reduction via flexible high recovery RO system was evaluated through analysis of treatment options on a laboratory scale. The naturally available gooseberry seed used as a coagulant in phase-1. It reduced $99.3 \%$ of TDS and hardness. It also increases the DO level of $\mathrm{RO}$ reject water, at the same time it increases turbidity and color. Turbidity and color removed by surface-modified zeolite in the phase-2. The zeolite material was taken in temperature $400^{\circ} \mathrm{C}$ as adsorbent of $6 \mathrm{~cm}$ column achieved 8NTU in $150 \mathrm{mmin}$. The $12 \mathrm{~cm}$ column was achieved 7.5NTU in 150 mins. Thomas and Thomson modelling well fitted with an experimental study. The regression correlation reached up to $0.942,0.9810$ and 0.984 . It is apparent from the recorded SEM patterns study. This study concludes that the coagulation by Goosperry seed produced the highest removal of TDS and hardness and in the adsorption process, with $400^{\circ} \mathrm{C}$ enhances the surface morphology and porous structure indicates that heating with higher-level temperature enhances the adsorption capacity of the adsorbent material. The highest efficiency is observed in hydrothermal hotness.
\end{abstract}

Keywords: RO reject, coagulation, adsorption, zeolite, SEM analysis, column regeneration

*e-mail: senthilenvtce@gmail.com 


\section{Introduction}

Drinking water supplied in water - stressed countries was satisfied by desalination of sea water, brackish and recycled water. The treatment of Reverse osmosis wastewater treatment is an invetiable and an unavoidable technology for the current scenario. Reverse osmosis (RO) is the process of removing bulk particles, ions and molecules from the drinking water by using a semi-permeable membrane. The wastewaters extracted from the RO system have high TDS and salinity content [1]. In the RO system, the wastewater having lower molecular waster is passed through the semi-permeable membrane and higher molecular as wastewater [2]. The RO plant installed in the household discharges the high quantity of wastewater with high TDS concentration about 40,000-50,000 mg/L along, with sodium and potassium salt saturation point of 400,000-600,000 $\mathrm{mg} / \mathrm{L}$ [3]. The dominant expulsion component in membrane filtration is stressful prohibition, to achieve consummate efficiency while paying little attention to parameters, like the fixation and weight of the arrangement. The treatment process involves high cost and complex operation [4]. In household level the RO water plant usage was unavoidable, to get pure and microbial free water, the RO plant was installed in the residential places. For 1 litre pure water 3 litre of wastewater was generated. Compared to reuse of $\mathrm{RO}$ wastewater it is high time to identify treatment technology for remediation of RO wastewater. The main intention of this study is to utilize the coagulation and adsorption process for treatment of wastewater. The naturally available gooseberry seed taken as coagulant and sand materials, which heated for $400^{\circ} \mathrm{C}$, used an adsorbent [5]. The coagulation is used to remove TDS and salinity but increases the color and turbidity [6]. To remove these two components the zeolite was used as adsorbent. The removal efficiency was measured by turbidity testing and direct color removal observation [7]. Thomas and Thomson's model were used to determine the internal and external mass transfer and the removal efficiency of the adsorption process [8]. The regression correlation value is matched and predicted with two models were used to find out the removal efficiency.

\section{Materials and Methods}

\section{Phase-1}

The sample collected from household RO plant (Model- Ultra aqua UX2111). For 15 mins of running condition, the collected quantity of treated water was 2.5 liter and RO rejects wastewater quantity was 2 liter [9]. In the treatment setup, two-phase of treatment was taken place; in the first phase, the coagulation was done with natural coagulant [10]. The goosperry seed was taken as a coagulant. The optimum dose was identified with the filed sample. The coagulation was performed with different concentrated coagulant [11]. Coagulants that are applied to the water are used to withdraw the forces that stabilize the colloidal particles and allow the particles to be suspended in the water. For one liter of the sample, the five different concentrations of coagulant was added as 1-5 gm, after adding the component and 20 mins running condition in different rpm level (100 rpm-500 rpm) [12], the turbidity level was checked with a different concentrated solution. The efficiency of the coagulation process was determined.

\section{Phase-2}

In this phase, the adsorption preceded with continuous column technique. The adsorbent prepared, and it was filled in the class column [13]. The adsorbent fabricated from naturally available zeolite material and surface area of the adsorbent is got activated for better adsorption [14]. The absorbent is heated to $400^{\circ} \mathrm{C}$, Sample flowed from the downstream side of the column. The diameter of the column was $2 \mathrm{~cm}$, the adsorbent packed for $6 \mathrm{~cm}$ and $12 \mathrm{~cm}$ sized column [15]. The higher heating temperature of adsorbent enhance the surface morphology and porous structure of colloidal particles. As the number of channels/cavities increased the surface area and heterogeneous nature of the materials, an observation of surface area indicates the presence of suspended and colloidal assortments. The quantity of the adsorbent was about $9 \mathrm{gm}$ and $16 \mathrm{gm}$. The inlet flow was $2 \mathrm{ml} / \mathrm{min}$ in the column, the output range about $1.6 \mathrm{ml} / \mathrm{min}$ [16]. The removal of color and turbidity was determined.

\section{Modeling Work}

\section{Thomas Model}

Thomas model is used to calculate the dependence of solute concentration with time. In continuous column technique, the internal and external mass transfer limitations were considered [17]. The model was given by

$$
\ln \left(C_{\mathrm{o}} / \mathrm{C}_{\mathrm{t}}-1\right)=\left(\mathrm{K}_{\mathrm{t}} * q * m / Q\right)-k_{t} * C_{\mathrm{o}} * \mathrm{t}
$$

...where $\mathrm{C}_{\mathrm{o}}$ and $\mathrm{C}_{\mathrm{t}}$-influent and effluent concentrations (mg/L), $\mathrm{K}_{\mathrm{t}}-$ Thomas rate constant (mL/ (min.mg), $\mathrm{m}$-the mass of adsorbent and $\mathrm{t}$ is a 76 time (min), The adsorption capacity of the bed $\mathrm{q}(\mathrm{mg} / \mathrm{g})$, Q was the quantity of adsorbent in the column (g) [18], the adsorption kinetics $\mathrm{k}_{\mathrm{t}}$ were determined from the plot of $\ln \left[\left(\mathrm{C}_{\mathrm{o}} / \mathrm{C}_{\mathrm{t}}\right)\right]$ against $\mathrm{t}$ at a constant flow rate [19]. The regression coefficient ranges represent the Thomas model. 


\section{Thomson Model}

Thomson model was used to find the inter relationship between external and internal processes of adsorption. The Thomson model can be expressed as

$$
\left(C_{\mathrm{o}} / \mathrm{C}_{\mathrm{t}}-1\right)=\left(\mathrm{k}_{\mathrm{TH}} \mathrm{q}_{\mathrm{e}} \mathrm{W}-\mathrm{k}_{\mathrm{TH}} \mathrm{C}_{\mathrm{o}} * \mathrm{t}\right) / \mathrm{Q}
$$

...where $\mathrm{k}_{\mathrm{TH}}-$ Thomson rate constant (ml/min.mg), $\mathrm{q}_{\mathrm{e}}$ is the adsorption capacity, $\mathrm{C}_{\mathrm{o}}$ - inlet ion concentration, $\mathrm{C}_{\mathrm{t}}$ - effluent ion concentration at time $\mathrm{t}(\mathrm{mg} / \mathrm{L})$ (Zahra et al. 2020), W -mass of adsorbent (g), Q is the inlet flow rate $(\mathrm{ml} / \mathrm{min})$, and $\mathrm{t}$-flow time $\mathrm{t}$ (min) [20]. The value of $C_{o} / C_{t}$ - the ratio of the inlet to the outlet ion concentrations. $\ln \left(C_{o} / C_{t}-1\right)$ against time (t) was strained to establish the values of $\mathrm{q}_{\mathrm{e}}$ and $\mathrm{k}_{\mathrm{TH}}$ from the interception point and slope of the plot [21], respectively.

\section{Characterization of Floc and Adsorbent}

The surface morphology of floc in coagulation and adsorbent characterized by SEM analysis. Naturally available material (Goosperry seed) used as a coagulant and surface-modified zeolite used as adsorbent [22]. The monitoring of pores in the surface area was essential to determine the efficiency of the adsorption process.

\section{Column Regeneration}

The packaged column was dismantled and the adsorbent carrying the turbid compound [23]. The adsorbent washed twice in distilled water and Sodium Chloride $(\mathrm{NaCl})$ solution and result in the removal of other substances and other components, present in adsorbent material Christopher and Jonathan (2015), which was exposed to evaporation under the sun for 8 hours.

\section{Result and Discussion}

\section{Water Quality of RO Reject}

The samples for the treatment process were collected from $\mathrm{RO}$ reject by manually to determine the quality of water. According to $\mathrm{WHO}$, the $\mathrm{pH}$ value of $\mathrm{RO}$ reject is collected from the household sample is found to be 8.5 is alkaline nature. The turbidity was 6 NTU which indicated that it was in a permissible limit. The hardness of the sample was the higher range of $2800 \mathrm{mg} / \mathrm{L}$ and TDS also at an alarming range of $816 \mathrm{mg} / \mathrm{L}$. The dissolved oxygen ranged below the acceptable limit as $3.5 \mathrm{mg} / \mathrm{L}$. The BOD was at the rising range of $0.3 \mathrm{mg} / \mathrm{L}$; likewise COD was also a higher level of $0.6 \mathrm{mg} / \mathrm{L}$. The analysis evidenced that reject from the RO plant had higher hardness and TDS level [24]. For the multi-phase treatment process, has to be conducted by the quality water, it is essential to determine the water quality before and after the treatment process for an estimate the treatment efficiency [25].

\section{Removal of TDS, Hardness and DO by Coagulation Process}

The coagulation process was chosen for the phase-1 treatment process, Goosperry seeds well grained, converted into powdered material and taken as coagulant [26]. The coagulant added in a powdered form in a different ratio to find out the optimum coagulant range. The initial TDS level was at $2600 \mathrm{mg} / \mathrm{L}$, hardness $250 \mathrm{mg} / \mathrm{L}$ and DO were $3.5 \mathrm{mg} / \mathrm{L}$ and the dose taken as 2, 4, 6 and $8 \mathrm{mg} / \mathrm{L}$. The TDS is observed in the range of 2600, 2524, 2000 and $2004 \mathrm{mg} / \mathrm{L}$ within the acceptable limit of WHO. The hardness determined in the range of $385,335,263,226 \mathrm{mg} / \mathrm{L}$ and the dissolved oxygen ranged from 3.5, 3.8, 4.7 and $4.9 \mathrm{mg} / \mathrm{L}$ [27]. This study proved that the main component of water quality parameters insisted on the positive output of the coagulation process [28]. The agitation given by jar test apparatus enumerates the water quality parameters in a better way. The different dose of coagulant produced the various reactions in the effluent. The second jar has obtained the optimum level of efficiency [29]. In this part, $6 \mathrm{gm}$ of coagulant added in 1 litre effluent and it mixed in a different rpm level. At the same time, the level of turbidity and the effluent changed into green color because of the presence of pigment chlorophyll in Goosperry seed.

\section{Optimization Based on the $\mathrm{pH}$ Level}

The synthesized column is performed to determine turbidity and color removal efficiency. The study revealed that maximum adsorption of turbidity by zeolite adsorbent occurred at $\mathrm{pH} 7.2$ [30], while the efficiency decreases at higher $\mathrm{pH}$. At $\mathrm{pH} 7.2$ surfaces has a charge which attracts the charged turbid molecules and adsorption occurs through electrostatic interactions [31]. However, when $\mathrm{pH}$ increases adsorbent acts as a charged particle and an electrostatic barrier developed between the negative surfaces of zeolite adsorbent. During this scenario, adsorption strongly inhibited resulting in the reduction within the adsorption rate [32]. In determining the $\mathrm{pH}$ level of the surface charges in zeolite adsorbents played an important role.

\section{Adsorption with a Zeolite Material}

The completion of phase-1 produced superior performance in the removal of TDS and hardness. Phase- 2 intended to remove turbidity and color from the treated effluent [33]. The fine zeolite activated by heating upto $400^{\circ} \mathrm{C}$ and it was packed in a glass column. The continuous adsorption mode is preceded. Samples released from top to bottom level. For every 15 min sample were collected and turbidity were 


\section{RO Reject wastewater}

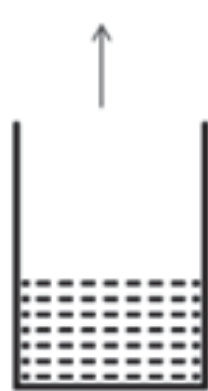

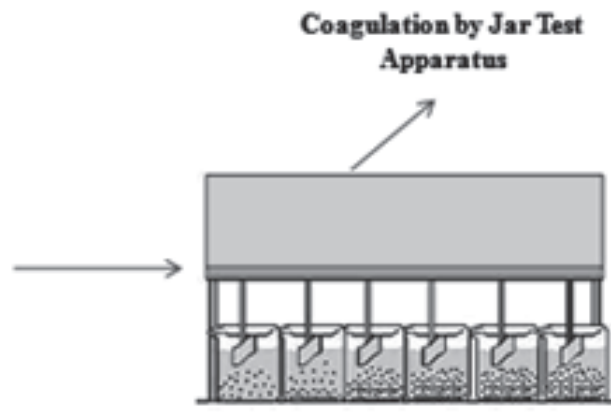

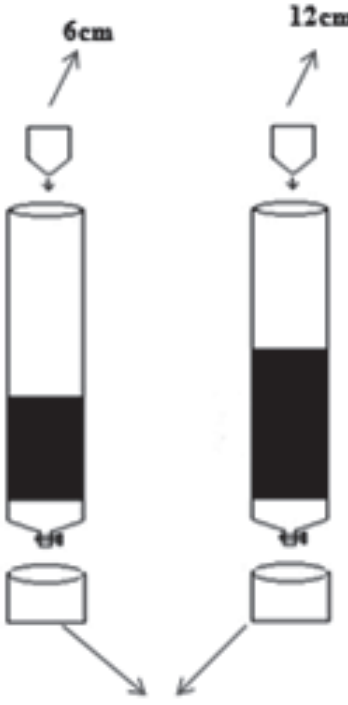

Adsorption Process

Fig. 1. Flow diagram of the integrated treatment system.

checked [34]. The color removal was studied by direct observation. For the $6 \mathrm{~cm}$ column, 135NTU of turbidity observed at the first 15 min collected sample. For $150 \mathrm{~min}$, the removal of turbidity observed as $8 \mathrm{NTU}$ and green colour shade removal is achieved $100 \%$. For $12 \mathrm{~cm}$, column the turbidity level $135 \mathrm{NTU}$ at first $15 \mathrm{mins}$ and $150 \mathrm{mins}$, it was 7.5NTU and the colour removal was $100 \%$ attained. As shown in Fig. 2 the removal efficiency gradually increased in $6 \mathrm{~cm}$ and $12 \mathrm{~cm}$ column and the column gets saturated about 150 mins when compared to $6 \mathrm{~cm}$ the removal proficiency is higher for $12 \mathrm{~cm}$ column due to the height of bed and time took for infiltration into adsorption bed.
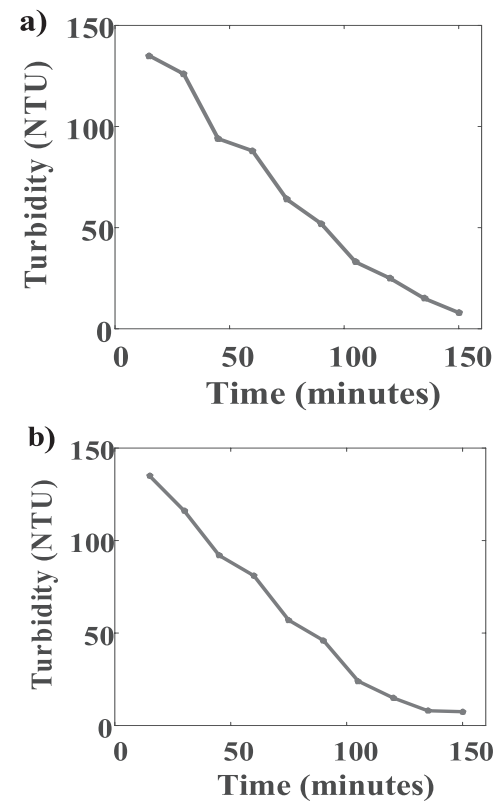

Fig. 2. a) Treatment efficiency of $6 \mathrm{~cm}$ zeolite Column and b) Treatment efficiency of $12 \mathrm{~cm}$ zeolite Column

\section{Thomas Model for Adsorption Study}

The progression of adsorption is controlled through ionic adsorption speciation and the binding site. The Thomas model assessed and the accuracy of the adsorption experimental and predicted development curve has been achieved [35]. The parametric statistic for $135 \mathrm{NTU}\left(\mathrm{R}^{2}\right)$ ranged from $0.901,0.914,0.927,0.900,0.916,0.914,0.910$, $0.921,0.964$ and 0.922 acknowledged that the Thomas model portrayed the column experimental data for the adsorption process alright. The worth of $\mathrm{k}_{\mathrm{t}}$ depends upon the mass $(\mathrm{m})$. Initially, $\mathrm{k}_{\mathrm{t}}$ values were in decreased condition and next level, $\mathrm{k}_{\mathrm{t}}$ (ml/ min.mg) values increased as $0.181,0.193$ and 0.213 which was given in Table 3 .

\section{Thomson Model for Adsorption Study}

The adsorption process for 135 NTU and the Table 4 showed that the Thomson rate constant $\mathrm{K}_{\mathrm{TH}}$ was $0.072 \mathrm{ml} / \mathrm{min} . \mathrm{mg}$ for $6 \mathrm{~cm}$ and it decreased to $0.009 \mathrm{ml} / \mathrm{min} . \mathrm{mg}$ [36]. The adsorption efficiency for $6 \mathrm{~cm}$, the column was $11.50 \mathrm{mg} / \mathrm{g}$ and for $12 \mathrm{~cm}$ it increased to $17.17 \mathrm{mg} / \mathrm{g}$ [37]. The regression coefficient of $6 \mathrm{~cm}$ was 0.954 and for $12 \mathrm{~cm}$ the correlation was 0.929 which showed compatible correlation.

\section{Characterization of Coagulant and Adsorbent}

SEM analysis of coagulant revealed mostly they were in pulverized nature due to powdery form it showed in the size of $10 \mu \mathrm{m}$ [38]. The study has developed the particles with an extra-ordinary stable side and found to be dispersed within the solution to avoid their mutual agglomeration (Fig. 3) The structures 
Table 1. Water Quality Characteristics of RO reject before the treatment process.

\begin{tabular}{|c|c|c|}
\hline Sl. No & Parameters & Values \\
\hline 1. & $\mathrm{pH}$ & 8.5 \\
\hline 2. & Turbidity (NTU) & 6 \\
\hline 3. & Hardness $(\mathrm{mg} / \mathrm{L})$ & 385 \\
\hline 4. & TDS $(\mathrm{mg} / \mathrm{L})$ & 2600 \\
\hline 5. & DO $(\mathrm{mg} / \mathrm{L})$ & 3.5 \\
\hline 6. & BOD $(\mathrm{mg} / \mathrm{L})$ & 0.3 \\
\hline 7. & COD $(\mathrm{mg} / \mathrm{L})$ & 0.6 \\
\hline
\end{tabular}

Table 2. Determination of TDS, Hardness and DO by coagulation.

\begin{tabular}{|c|c|c|c|c|}
\hline Sl. No & $\begin{array}{c}\text { Dose response } \\
(\mathrm{gm} / \mathrm{L})\end{array}$ & $\begin{array}{c}\text { TDS } \\
(\mathrm{mg} / \mathrm{L})\end{array}$ & $\begin{array}{c}\text { Hardness } \\
(\mathrm{mg} / \mathrm{L})\end{array}$ & $\begin{array}{c}\text { DO } \\
(\mathrm{mg} / \mathrm{L})\end{array}$ \\
\hline 1. & 2 & 2600 & 385 & 3.5 \\
\hline 2. & 4 & 2524 & 335 & 3.8 \\
\hline 3. & 6 & 2000 & 263 & 4.7 \\
\hline 4. & 8 & 2004 & 226 & 4.9 \\
\hline
\end{tabular}

Table 3. Validation of Thomas model for adsorption study.

\begin{tabular}{|c|c|c|}
\hline \multicolumn{3}{|c|}{ Thomas Model } \\
\hline $\mathrm{kt} \times 10^{-3}(\mathrm{ml} /($ min.mg $)$ & $\mathrm{q}_{\mathrm{o}}(\mathrm{mg} / \mathrm{g})$ & $\mathrm{R}^{2}$ \\
\hline 0.154 & 1.312 & 0.901 \\
\hline 0.142 & 0.201 & 0.914 \\
\hline 0.013 & 19.37 & 0.927 \\
\hline 0.011 & 19.21 & 0.900 \\
\hline 0.013 & 17.83 & 0.916 \\
\hline 0.012 & 15.72 & 0.914 \\
\hline 0.181 & 12.31 & 0.910 \\
\hline 0.193 & 14.34 & 0.921 \\
\hline 0.204 & 0.014 & 0.964 \\
\hline 0.213 & 18.10 & 0.922 \\
\hline
\end{tabular}

Table 4. Validation of Thomson model for adsorption study.

\begin{tabular}{|c|c|c|}
\hline Column Depth & $6 \mathrm{~cm}$ & $12 \mathrm{~cm}$ \\
\hline $\mathrm{q}_{\mathrm{e}(\mathrm{mg} / \mathrm{g})}$ & 11.50 & 17.17 \\
\hline $\mathrm{k}_{\mathrm{TH}}(\mathrm{ml} / \mathrm{min} \cdot \mathrm{mg})$ & 0.072 & 0.009 \\
\hline $\mathrm{R}^{2}$ & 0.954 & 0.929 \\
\hline
\end{tabular}

a)

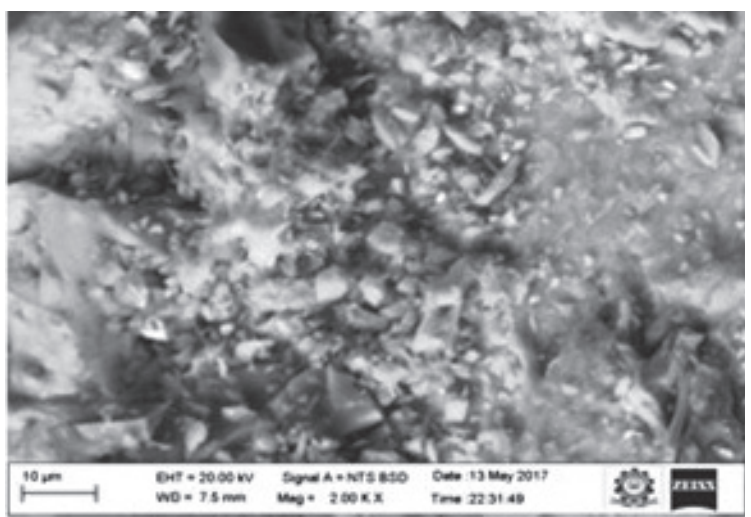

b)

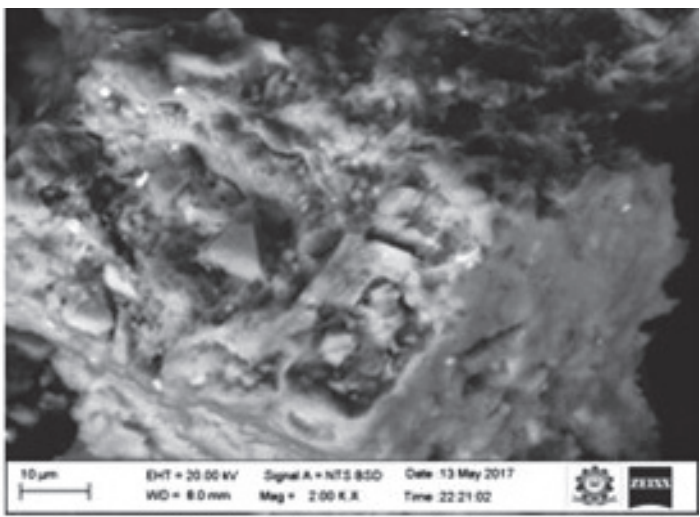

Fig. 3. a) SEM image of coagulant b) SEM image of Adsorbent.

of adsorbent after the adsorption process were pale petals with the smooth facade where channels and cavities were at micro-level [39]. The morphology of the packed column appears porous and rough with defined channels and cavities (Fig. 3) [40]. According to literature the pore morphological change of column material from homogeneous to heterogeneous formation is due to the drop off particle structure [4'].

\section{Regeneration of Adsorbent}

The adsorbent is an inert material of the turbid molecule adsorbed in the surface area of the column [42]. The $\mathrm{NaCl}$ wash and solar evaporation eradicated the turbidity and coloured particles in the surface area [43]. After the regeneration process, the adsorbent acted as a freshly prepared column [44]. It showed that the column had been used several times as an adsorbent [45].

\section{Conclusion}

Laboratory scale studies were carried out at the household RO plant installed to remove TDS, hardness, and turbidity with the application of coagulation and adsorption technique. In phase-1 the TDS and hardness removed by the coagulation process. The Gooseberry seed used as coagulant the optimum level determined by the various concentration levels. In this process TDS level reduced from $2600 \mathrm{mg} / \mathrm{L}$ to $2004 \mathrm{mg} / \mathrm{L}$, 
meanwhile, it was higher than the WHO limit of $500 \mathrm{mg} / \mathrm{Land}$ the hardness decreased to $226 \mathrm{mg} / \mathrm{L}$ from $385 \mathrm{mg} / \mathrm{L}$, it came under WHO permissible limit. Meantime the turbidity increased from $6 \mathrm{NTU}$ to $135 \mathrm{NTU}$. In phase- 2 to remove the excess turbidity and color level; the adsorption proceeded with zeolite as adsorbent. The increasing temperature of $400^{\circ} \mathrm{C}$ accelerated the adsorption capacity. Thus, the column study has exhibited with $6 \mathrm{~cm}$ have produced a turbidity level of $8 \mathrm{NTU}$ and $12 \mathrm{~cm}$, column produced 7.5NTU turbidity level as per the permissible limit of $10 \mathrm{NTU}$ recommended by WHO. The green colour shade goes to break down from the effluent by adsorption process, it observed by direct observation. These experimental studies investigated with Thomas and Thomson's modelling. The Thomas model well correlated with experimental study, the worth of $\mathrm{k}_{\mathrm{t}}$ depends upon the mass (m). Initially, $\mathrm{k}_{\mathrm{t}}$ values were in decreased condition and next level, $\mathrm{k}_{\mathrm{t}}(\mathrm{ml} / \mathrm{min} . \mathrm{mg})$ values increased as $0.181,0.193$ and 0.213 and the regression correlation was in the lane between $0.901-0.964$. The Thomson rate constant $\mathrm{K}_{\mathrm{TH}}$ was $0.072 \mathrm{ml} / \mathrm{min}$. $\mathrm{mg}$ for $6 \mathrm{~cm}$ and it decreased to $0.009 \mathrm{ml} / \mathrm{min}$. $\mathrm{mg}$. The adsorption efficiency for $6 \mathrm{~cm}$ column $11.50 \mathrm{mg} / \mathrm{g}$ and for $12 \mathrm{~cm}$ it increased as $17.17 \mathrm{mg} / \mathrm{g}$. The regression coefficient of $6 \mathrm{~cm}$ was 0.954 and for $12 \mathrm{~cm}$ the correlation 0.929 which showed compatible correlation. It showed an enhancement of surface morphology and porous structure indicated that heating with higher-level temperature enhanced the adsorption capacity of column material. Thus, the RO reject water has been utilized as recyclable water by the multifunctional treatment process. It suggested using this water for residential purpose in this hard water scarcity situation.

\section{Acknowledgement}

This work was supported by the Sethu Institute of Technology, Kariapatti, Tamil Nadu, India.

\section{Conflict of Interest}

The authors declare that they have no conflict of interest.

\section{References}

1. SINA NABATI SHOGHL., REZA NAZERIFARD., ABBAS NADERIFAR. Improvement of recovery of gaseous fluids using the replacement of supersonic separator instead of Joule-Thomson valve in dehydration/ NGL recovery unit with computational fluid dynamic modeling. Chemical Engineering Research and Design. 148, 1, 2019.

2. MOA MEGERSA, WIW GACH, ABEBE BEYENE, ARGAW AMBELU, LUDWIG TRIEST. Effect of salt solutions on coagulation performance of Moringastenopetala and Maeruasubcordata for turbid water treatment. International Journal of Separation and Purification Technology. 221, $319,2019$.

3. ALEXANDER S.M., WITTMAR., JONATHANKLUG., MATHIASULBRICHT. Cellulose/chitosan porous spheres prepared from 1-butyl-3-methylimidazolium acetate/dimethylformamide solutions for $\mathrm{Cu}^{2+}$ adsorption. International Jounral of Carbohydrate polymers. 237, 116135, 2020.

4. MIKA SILLANPAA., MOHAMED CHAKER NCIBI., ANU MATILAINEN., MIKKO VEPSALAINEN. Removal of natural organic matter in drinking water treatment by coagulation: A comprehensive review. Journal of Chemosphere, 190, 54, 2018.

5. MOA MEGERSA, WIW GACH, ABEBE BEYENE, ARGAW AMBELU, LUDWIG TRIEST. Effect of salt solutions on coagulation performance of Moringastenopetala and Maeruasubcordata for turbid water treatment. International Journal of Separation and Purification Technology. 221, 319, 2019.

6. THAYYATH., S.ANIRUDHAN., F.SHAINYJ.CHRISTA. Synthesis and characterization of polyacrylic acid- graftedcarboxylic graphene/titanium nanotube composite for the effective removal of enrofloxacin from aqueous solutions: Adsorption and photocatalytic degradation studies. Journal of hazardous materials. 324, Part B, 117, 2017.

7. XIAOJIE QIAN., KAI LIU, HAIRUI YAO., XIONGFEI YIN., GUANGTAO ZHAO., BINGCHEN WANG., HAIMEI LI. Effect of Anion Surfactants on the Adsorption of Polycyclic Aromatic Hydrocarbons on Sediment under Estuarine Mix Conditions. Pol. J. Environ. Stud. 29 (2), 1793, 2020.

8. BRITTANY A.NORDMARK., TODD M.PRZYBYCIEN., ROBERT D.TILTON. Effect of humic acids on the kaolin coagulation performance of Moringaoleiferaproteins. International Journal of Environmental Chemical Engineering. 6 (4), 4564, 2018.

9. KIM CHOON NG, KYAW THU, YOUNGDEUK KIM, ANUTOSH CHAKRABORTY, GARY AMY. Adsorption desalination: An emerging low-cost thermal desalination method. Journal of Desalination, 308, 161, 2013.

10. SENTHIL KUMAR M., GOPALA KRISHNA G.V.T., SIVASANKAR V. Coagulation performance evaluation of natural and synthetic coagulants in waste water treatment. ARPN Journal of Engineering and Applied Sciences, Scimago, 10 (6), 2715, 2015.

11. RAHMAT ULLAH., FAIZA JAN IFTIKHAR., MUHAMMAD AJMAL., AFZAL SHAH., MOHAMMAD SALIM AKHTER., HASEEB ULLAH., AMIR WASEEM. Modified clays as an efficient adsorbent for brilliant green, ethyl violet and allura red dyes: Kinetic and thermodynamic studies. Polish Journalof Environmental Studies. 29 (5), 1, 2020.

12. B.K.ZAIED., MAMUNUR RASHID., MOHD NASRULLAH., A.W.ZULARISAM., DEEPAK PANT., LAKHVEER SINGH.A comprehensive review on contaminants removal from pharmaceutical wastewater by electrocoagulation process. Inter journal of Science of the total environment. In press, 2020.

13. XIAOJIE QIAN., KAI LIU, HAIRUI YAO., XIONGFEI YIN., GUANGTAO ZHAO., BINGCHEN WANG., HAIMEI LI. Effect of Anion Surfactants on the Adsorption of Polycyclic Aromatic Hydrocarbons on Sediment under Estuarine Mix Conditions. Pol. J. Environ. Stud. 29 (2), 1793, 2020. 
14. SENTHIL KUMAR M., GOPALAKRISHNA G.V.T., SIVASANKAR V. Coagulation performance evaluation of natural and synthetic coagulant in waste water treatment. ARPN journal of engineering and applied sciences. 10, 6, 2015.

15. VENKATARAMAN SIVASANKAR., KIYOSHI OMINE., TITUS ALFRED MAKUDALI MSAGATI., M.SENTHIL KUMAR., ABIMANYU CHANDRAMOHAN. Evaluation of groundwater quality in Madurai City, South India for drinking, irrigation and construction purposes.Arabian Journal of Geosciences 7, 3093, 2013.

16. BOON-CHINLIM.,JUN-WEI LIM., YEEK-CHIA HO. Garden cress mucilage as a potential emerging biopolymer for improving turbidity removal in water treatment. Process safety and Environmental Protection, 119, 233, 2020.

17. SENTHIL KUMAR M., SIVASANKAR M., GOPALAKRISHNA G.V.T. Quantification of benzene in groundwater sources and risk analysis in a popular south Indian pilgrimage city-A GIS based approach. Arabian Journal of chemistry 10, S2523, 2017.

18. MASSOUMEH MANOUCHEHRI., ALI KARGARI. Water recovery from laundry wastewater by the cross flow microfiltration process: A strategy for water recycling in residential buildings. International Journal of cleaner production, 168, 227, 2020.

19. GAYATHRI NAIDU., SANGHYUN JEONG., YOUNGKWON CHOI., SARAVANAMUTHU VIGNESWARAN. Membrane distillation for wastewater reverse osmosis concentrate treatment with water reuse potential. International Journal of membrane science. 524, $565,2017$.

20. SEYYEDEH COBRA AZIMI., FARHAD SHIRINI., ALIREZA PENDASHTEH. Evaluation of COD and turbidity removal from woodchips wastewater using biologically sequenced batch reactor. Journal of Process Safety and Environmental Protection. 128, 211, 2019.

21. PODGORSKA M., JOZWIAK M. Impact of Former Iron Ore Mining on Soil Cover in the Northern Foreland of Poland's swiętokrzyskie Mountains. Polish Journal of Environmental Studies, 29 (4), 2813, 2020.

22. OLADOJA N.A., SALIUI T.D., OLOLADEE A., ANTHONYG T., BELLO A. A new indigenous green option for turbidity removal from aqueous system. International journal of Separation and Purification Technology. 186 (2), 166, 2017.

23. JAMES S. ROSENBLUM, KURBAN A. SITTERLEY, E. MICHAEL THURMAN, IMMA FERRER, KARL G. LINDEN Hydraulic fracturing wastewater treatment by coagulation-adsorption for removal of organic compounds and turbidity. International Journal of Environmental Chemical Engineering. 04 (02), 19781984, 2020.

24. NAN WANG., XING LI., YANLING YANG., ZHIWEI ZHOU., YI SHANG., XIAOXUAN ZHUANG Photocatalysis-coagulation to control ultrafiltration membrane fouling caused by natural organic matter. International Journal of cleaner production. In press, 121790, 2020.

25. ZAHRA FERASAT., REZA PANAHI. Natural polymer matrix as safe flocculant to remove turbidity from kaolin suspension: Performance and governing mechanism. Journal of Environmental Management. 255, 2020.

26. DAISUKETANIKAWA., TAIKIKATAOKA., HIDEAKIS ONAKA., YUGAHIRAKATA., MASASHI HATAMOTO., TAKASHI YAMAGUCHI. Evaluation of key factors for residual rubber coagulation in natural rubber processing wastewater. International Journal of water processing Engineering. 33 (2), 356, 2020.

27. SURACHAI WONGCHAREE., VASANTHA ARAVINTHAN., LASZLO ERDEI. Removal of natural organic matter and ammonia from dam water by enhanced coagulation combined with adsorption on powdered composite nano-adsorbent. Journal of Environmental Technology \& Innovation. 7, 100557, 2020.

28. YASUKAWA., TASUMA SUZUKI., MITSURU HIGA. Reverseelectrodialysis for power generation using seawater/municipal wastewater: Effect of coagulation pretreatment. Journal of Desalination. 481, 114356, 2020.

29. NADIA AYUB., ABDUL MANNAN EHSAN., MUHAMMAD NAWAZ CHAUDHRY. Using AcidActivated Azad Kashmir Clays to Remove Cadmium and Lead Ions from Wastewater. Polish Journal Environmental Studies. 29 (5), 1, 2020.

30. ASL GOCENOGLU SARIKAYA. Adsorptive Removal of Textile Dye Direct Blue 9 from Aqueous Solution by NanoSized Polymers: Kinetic and Thermodynamic Studies. Polish Journal Environmental Studies. 29 (4), 2845, 2020.

31. MOA MEGERSA, WIW GACH, ABEBE BEYENE, ARGAW AMBELU, LUDWIG TRIEST. Effect of salt solutions on coagulation performance of Moringastenopetala and Maeruasubcordata for turbid water treatment. International Journal of Separation and Purification Technology. 221, $319,2019$.

32. BOON-CHINLIM., JUN-WEI LIM., YEEK-CHIA HO. Garden cress mucilage as a potential emerging biopolymer for improving turbidity removal in water treatment. Process safety and Environmental Protection, 119, 233, 2020.

33. SINA NABATI SHOGHL., REZA NAZERIFARD., ABBAS NADERIFAR. Improvement of recovery of gaseous fluids using the replacement of supersonic separator instead of Joule-Thomson valve in dehydration/ NGL recovery unit with computational fluid dynamic modeling. Chemical Engineering Research and Design. 148, 1, 2019.

34. SINA NABATI SHOGHL., REZA NAZERIFARD., ABBAS NADERIFAR. Improvement of recovery of gaseous fluids using the replacement of supersonic separator instead of Joule-Thomson valve in dehydration/ NGL recovery unit with computational fluid dynamic modeling. Chemical Engineering Research and Design. 148, 1, 2019.

35. YONGJUN SUN., SHENGBAO ZHOU., PEN-CHI CHIANG., KINJAL J. SHAH. Evaluation and optimization of enhanced coagulation process: Journal of Water and energy nexus. Water-Energy Nexus, 02, 25, 2019.

36. ANDREWTURNER., KAI TING WU. Removal of platinum group elements in an estuarine turbidity maximum. Marine Chemistry, 107, 295, 2007.

37. WU Y., ZALEWSKI D.R., VERMEER C.H., HOLLANDH.J. Baseline design of a sorption-based JouleThomson cooler chain for the METIS instrument in the E-ELT. Cryogenics. 84, 37, 2017.

38. KANG XIAO., XIAOMAO WANG., XIA HUANG., DAVID WAITE., XIANGHUA WEN. Analysis of polysaccharide, protein and humic acid retention by microfiltration membranes using Thomas' dynamic adsorption model. Journal of membrane science. 342, 22, 2009.

39. CHRISTOPHER M.BURBA., JONATHAN JANZEN. Confinement effects on the phase transition temperature 
of aqueous $\mathrm{NaCl}$ solutions: The extended Gibbs-Thomson equation. ThermochimicaActa. 615, 81, 2015.

40. ZIZENG LIN., HAI YANG., HUIMING CHEN., XINYU OUYANG., ZHAOQIN LIU. Comparison of the Decontamination Performance of Three Permeable Bricks: Adsorption and Filtration Experiments. Polish Journal of Environmental Studies, 29 (5), 1, 2020.

41. ALEXANDER S.M., WITTMAR., JONATHANKLUG., MATHIASULBRICHT. Cellulose/chitosan porous spheres prepared from 1-butyl-3-methylimidazolium acetate/dimethylformamide solutions for $\mathrm{Cu}^{2+}$ adsorption. International Jounral of Carbohydrate polymers. 237, 116135, 2020.

42. MIKA SILLANPAA., MOHAMED CHAKER NCIBI., ANU MATILAINEN., MIKKO VEPSALAINEN. Removal of natural organic matter in drinking water treatment by coagulation: A comprehensive review. Journal of Chemosphere, 190, 54, 2018.
43. ASRAR AHMAD., SHABBIR HUSSAIN., SAJID MAHMOOD RAO., AMINA ASGHAR., MISBAH IRSHAD., MUHAMMAD ASLAM., SYED SALMAN SHAFQAT., MOHSIN JAVED., MUHAMMAD SHAHZAD BASHIR., HAFIZA SAMREEN KAUSAR. Comparative Studies of Lead and Heavy Metals Concentrations in Pakistan Soil and Its Toxic Effects. Polish Journal of Environ. Stud. 29 (4), 2433, 2020.

44. HOSSEIN MOHAMMADPOUR., MAHDI SHAHRIARINOUR., RAMIN YOUSEFI. Benzene Degradation by Free and Immobilized Bacillus glycinifermantansStrain GO-13T Using GO Sheets. Polish Journal of Environmental Studies, 29 (4), 2783, 2020.

45. NICOLAS BEAUCHAMP., CHRISTIAN BOUCHARD., CAETANO DORE., MANUEL RODRIGUEZ. Ultraviolet absorbance monitoring for removal of DBP-precursor in waters with variable quality: Enhanced coagulation revisited. Inter Journal Science of the Total Environment, 717, 137225, 2020. 